Article

\title{
Electronic and steric factors for enhanced selective synthesis of 2-ethyl-1-hexanol in the Ir-complex-catalyzed Guerbet reaction of 1-butanol
}

\author{
Zhanwei Xu a, Peifang Yan a, Changhui Liang a,b, Songyan Jia c, Xiumei Liu a , Z. Conrad Zhang a,* \\ a State Key Laboratory of Catalysis, Dalian National Laboratory for Clean Energy, Dalian Institute of Chemical Physics, Chinese Academy of Sciences, \\ Dalian 116023, Liaoning, China \\ b University of Chinese Academy of Sciences, Beijing 100049, China \\ c College of Chemical Engineering, Shenyang University of Chemical Technology, Shenyang 110142, Liaoning, China
}

\section{A R T I C L E I N F}

\section{Article history:}

Received 25 December 2020

Accepted 22 January 2021

Available online 5 May 2021

\section{Keywords:}

2-Ethyl-1-hexanol

Guerbet reaction

1-Butanol

Iridium

Hydrogenation

\begin{abstract}
A B S T R A C T
1-Butanol is a potential bio-based fermentation product obtained from cellulosic biomass. As a value-added chemical, 2-ethyl-1-hexanol (2-EH) can be produced by Guerbet conversion from 1-butanol. This work reports the enhanced catalytic Guerbet reaction of 1-butanol to 2-EH by a series of $\mathrm{Cp}^{*}$ Ir complexes (Cp*: 1,2,3,4,5-pentamethylcyclopenta-1,3-diene) coordinated to bipyridine-type ligands bearing an ortho-hydroxypyridine group with an electron-donating group and a $\mathrm{Cl}^{-}$anion. The catalytic activity of the Cp*Ir complex increased by increasing the electron density of the bipyridine ligand when functionalized with the para- $\mathrm{NMe}_{2}$ and ortho-hydroxypyridine groups. A record turnover number of 14047 was attained. A mechanistic study indicated that the steric effect of the ethyl group on the $\alpha$-C of 2-ethylhexanal (2-EHA) and the conjugation effect of $\mathrm{C}=\mathrm{C}-\mathrm{C}=0$ in 2-ethylhex-2-enal (2-EEA) benefits the high selectivity of 2-EH from 1-butanol by inhibiting the cross-aldol reaction of 2-EHA and 2-EEA with butyraldehyde. Nuclear magnetic resonance study revealed the formation of a carbonyl group in the bipyridine-type ligand via the reaction of the $\mathrm{Cp}^{*} \mathrm{Ir}$ complex with $\mathrm{KOH}$.
\end{abstract}

(C) 2021, Dalian Institute of Chemical Physics, Chinese Academy of Sciences. Published by Elsevier B.V. All rights reserved.

\section{Introduction}

The development of renewable chemicals from biomass remains one of the most important objectives for attaining global sustainability. 2-Ethyl-1-hexanol (2-EH), one of the "plasticizer alcohols," has been used in polyvinyl chloride manufacturing [1]. Moreover, 2-EH has been extensively applied in the production of soaps, surfactants, solvents, adhesives, diesel, and lube additives. The industrial three-step production of 2-EH involves the hydroformylation of propylene with $\mathrm{CO}$ and hydrogen gas to butyraldehyde, and base-catalyzed aldol condensation of butyraldehyde to 2-ethyl-2-hexenal, followed by hydrogenation of 2-ethyl-2-hexenal with hydrogen gas (Scheme 1) [2-4]. Recent progress has been made to integrate the aldol condensation of butyraldehyde and hydrogenation of 2-ethyl-2-hexenal into a one-pot reaction [5,6]. However, industrial processes still depend on unsustainable fossil carbon resources, and external $\mathrm{CO}$ and hydrogen gas are required.

The abundance of cellulosic biomass provides an environmentally beneficial, renewable feedstock as an alternative to

* Corresponding author. Tel/Fax: +86-411-84379462; E-mail: zczhang@yahoo.com

This work was supported by the National Natural Science Foundation of China $(21706255,21932005,21690084)$.

DOI: 10.1016/S1872-2067(20)63772-X | http://www.sciencedirect.com/journal/chinese-journal-of-catalysis | Chin. J. Catal., Vol. 42, No. 9, September 2021 


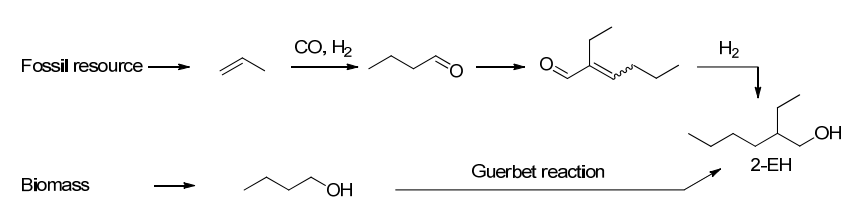

Scheme 1. Alternative route for the synthesis of 2-ethyl-1-hexanol.

fossil carbon resources to produce chemicals and fuels. The Guerbet reaction has been used for upgrading biomass-based light alcohols to value-added higher alcohols. For example, the Guerbet reaction of ethanol, a fermentation product of sugar-containing crops, has been studied to produce 1-butanol as an "advanced biofuel." Heterogeneously and homogeneously catalyzed Guerbet reactions of ethanol to 1-butanol have been reported [7-20]. 1-Butanol is also a potential fermentation product obtained via the acetone-butanol-ethanol fermentation process [21-24].

The synthesis of 2-EH from the Guerbet reaction of 1-butanol is a green alternative process (Scheme 1). The hydrogen required for the Guerbet reaction is borrowed in situ from the dehydrogenation of 1-butanol and does not involve the typical $\mathrm{H}_{2}$ dissociation step [15,25,26]. Compared with the conventional three-step process in the production of 2-EH from fossil resources, the synthesis of 2-EH through the Guerbet reaction offers technical and potentially economic advantages, as it is a one-step process that eliminates the need for operations under pressurized $\mathrm{CO}$ and $\mathrm{H}_{2}$. Heterogeneous catalysts, such as Ir on $\mathrm{N}$-doped carbon and Pd on metal oxides, have been applied for the Guerbet reaction of 1-butanol to 2-EH under a high temperature $\left(>170{ }^{\circ} \mathrm{C}\right)$ with byproducts including olefins, ethers, and higher alcohols [27-29]. Homogeneous catalysts, such as Ir complexes, have been reported to exhibit good catalytic dehydrogenation/hydrogenation functions involved in the Guerbet reaction of 1-butanol. Ishii et al. [30] reported that $\left[\mathrm{Cp}^{*} \mathrm{IrCl}_{2}\right]_{2}$ or $[\operatorname{IrCl}(\mathrm{COD})]_{2} \quad\left(\mathrm{Cp}^{*}\right.$ for 1,2,3,4,5-pentamethylcyclopenta-1,3-diene, and COD for cycloocta-1,5-diene) complex catalyzed the Guerbet reaction of 1-butanol to 2-EH in the presence of a ${ }^{t} \mathrm{BuOK}$ base catalyst in xylene at $120{ }^{\circ} \mathrm{C}$. However, the performance of the Ir complex measured by the turnover number (TON) was less than 100. Xu et al. [31] reported that $\mathrm{IrCl}_{3}$ combined with a functionalized 1,10-phenanthroline ligand in the presence of the required stoichiometric $\mathrm{KOH} / \mathrm{NaOAc}$ base-catalyzed Guerbet reaction of 1-butanol yielded a TON of approximately 250 in water at 150 ${ }^{\circ} \mathrm{C}$. Given the current state of progress, developing an efficient catalyst with high activity and selectivity is an important but highly challenging research goal for enhanced productivity for the Guerbet reaction of 1-butanol to 2-EH. This work aims to identify the critical structural and functional factors of ligands in the catalyst design for enhanced performances of Ir complexes in the Guerbet reaction of 1-butanol to 2-EH.

The Guerbet reaction of 1-butanol involves the following catalytic sequence: (1) metal-catalyzed dehydrogenation of 1-butanol to butyraldehyde, (2) base-catalyzed aldol condensation of butyraldehyde, and (3) metal-catalyzed hydrogenation of the aldol condensation product [32-34]. Although Ir complexes exhibited the potential for Guerbet catalysis of 1-butanol, the reported catalytic performance measured by TON was less than 1000 [30,31]. Developing an efficient metal catalyst with superior performance for both dehydrogenation and hydrogenation is critical for enhanced performance in the Guerbet reaction of 1-butanol to 2-EH. The Cp*Ir complexes coordinated by pyridine-type ligands bearing an ortho-hydroxypyridine group (a proton-response ligand) are a class of excellent catalysts for hydrogenation/dehydrogenation, such as the hydrogenation of $\mathrm{CO}_{2}$ and 5-hydroxymethylfurfural (5-HMF), and the dehydrogenation of alcohol and formic acid [35-48]. We previously demonstrated the excellent performance of a series of $\mathrm{Cp}^{*} \mathrm{Ir}$ complexes coordinated with bipyridine-type ligands bearing an ortho-hydroxypyridine group for the hydrogenation of 5-HMF to 1-hydroxyhexane-2,5-dione (HHD) with a turnover frequency (TOF) of $31560 \mathrm{~h}^{-1}[39,40]$. The equilibrium reaction of ortho-hydroxypyridine to ortho-oxyanion was found to assist $\mathrm{H}_{2}$ heterolytic dissociation. The strong electron-donating $\mathrm{NMe}_{2}$ group on the bipyridine-type ligand was found to further enhance the high catalytic performance for hydrogenating aldehyde and olefin intermediates, resulting in the TOF of hydrogenating 5-HMF to HHD [40]. In this work, the in situ formed ortho-oxyanion as a base is expected to assist the deprotonation of 1-butanol, as well as to enhance the performance of the subsequent hydrogenation of the in situ generated aldol condensation intermediate, leading to an enhanced catalytic performance of the Guerbet reaction of 1-butanol catalyzed by the Cp*Ir complex. Based on the above hypothesis, we synthesized Cp*Ir complexes bearing an ortho-hydroxypyridine group, which are electron-donating groups targeted for Guerbet catalysis in this work (Scheme 2). The $\mathrm{Cp}$ *Ir complex bearing an electron-donating group, ortho-hydroxypyridine, and a $\mathrm{Cl}^{-}$anion, is favorable for the Guerbet reaction of 1-butanol to 2-EH under mild conditions. A mechanism for the $\mathrm{Cp}$ *Ir complex-catalyzed Guerbet reaction of 1-butanol to 2-EH is proposed.

\section{Experimental}

All the reagents used were of analytical grade, purchased locally and used without any purification unless otherwise specified. NMR spectra were measured in $\mathrm{CDCl}_{3}$, or $\mathrm{CD}_{3} \mathrm{OD}$ on a $400 \mathrm{MHz}$ instrument and recorded at the following frequencies: proton $\left({ }^{1} \mathrm{H}, 400 \mathrm{MHz}\right)$, carbon $\left({ }^{13} \mathrm{C}, 100 \mathrm{MHz}\right)$.

Synthesis of [Cp*IrClL4]Cl: a mixture of $\mathrm{Cp}^{*} \mathrm{IrCl}_{2}(100 \mathrm{mg})$, L4 (64.3 mg) was stirred in methanol $(20 \mathrm{~mL})$ under $\mathrm{N}_{2}$ at-

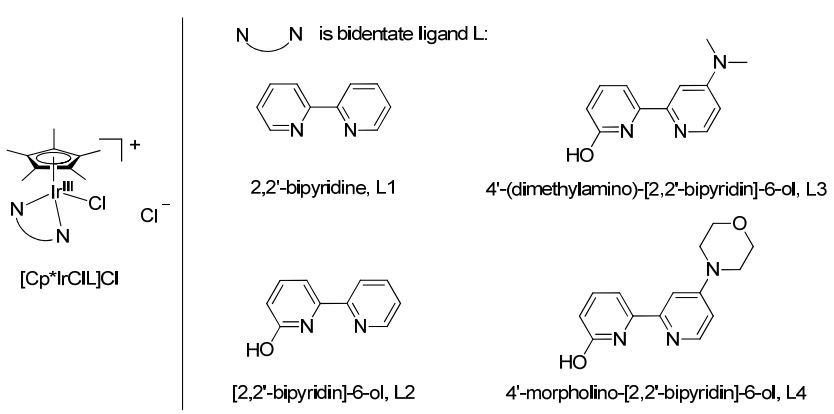

Scheme 2. Chemical structures of $\mathrm{Cp}^{*} \mathrm{Ir}$ complexes in this work. 
mosphere at room temperature for $12 \mathrm{~h}$. The methanol solution was removed under vacuum to give the product as a yellow solid. The yellow solid was used for Guerbet catalysis without further purification. ${ }^{1} \mathrm{H} \mathrm{NMR}\left(400 \mathrm{MHz}, \mathrm{CD}_{3} \mathrm{OD}\right) \delta 1.64(\mathrm{~s}, 15 \mathrm{H})$, 3.60-3.62 (m, 4H), 3.82-3.84 (m, 4H), 7.07-7.11 (m, 2H), 7.65 $(\mathrm{d}, J=2.8,1 \mathrm{H}), 7.88-7.99(\mathrm{~m}, 2 \mathrm{H}), 8.36(\mathrm{~d}, J=6.92,1 \mathrm{H}) ;{ }^{13} \mathrm{C}$ NMR (100 MHz, CD $\left.{ }_{3} \mathrm{OD}\right) \delta 8.0,65.9,88.5,106.2,110.6,112.7$, $114.4,141.8,150.1,153.9,155.9,156.2,164.0$.

Guerbet reaction of 1-butanol: As shown in Table 1, a mixture of $\mathrm{Cp}^{*}$ Ir complex, 1-butanol (2.0 g), and $\mathrm{KOH}$ was stirred under $\mathrm{N}_{2}$ atmosphere. The final reaction mixture was diluted by $\mathrm{CH}_{3} \mathrm{CN}$, and dioxane was added as an internal standard for GC analysis. The TON was calculated based on converted 1-butanol in the products.

\section{Results and discussion}

We first tested the $\left[\mathrm{Cp}^{*} \mathrm{IrCl}_{2}\right]_{2}$ complex without a bipyridine-type ligand as the catalyst for the Guerbet reaction of 1-butanol with $\mathrm{KOH}$ as the base catalyst. The TON reached 411 in $6 \mathrm{~h}$, and the desired 2-EH product was obtained with a selectivity of $74.3 \%$ (Table 1, entry 1). 2-Ethylhexanal (2-EHA), 2-ethylhex-2-enal (2-EEA), and 2-ethylhex-2-en-1-ol (2-EHE) were also detected with selectivities of $4.1 \%, 2.9 \%$, and $18.7 \%$, respectively. In comparison, the [Cp*IrClL1]Cl complex achieved a TON of 629, indicating that the bipyridine ligand L1 significantly enhanced the catalytic activity of the $\mathrm{Cp}^{*} \mathrm{Ir}$ complex (Table 1, entry 2). To assess the effect of the ortho-hydroxypyridine group, the catalytic activity of [Cp*IrClL2]Cl with an ortho-hydroxypyridine group was tested for comparison (Table 1, entry 3). The TON of the [Cp*IrClL2]Cl complex nearly doubled that of the [Cp*IrClL1]Cl complex, indicating that the ortho-hydroxypyridine group of the bipyridine-type ligand played an important role in the formation of 2-EH, probably because the ortho-hydroxypyridine group assisted the dehydrogenation of 1-butanol and the subsequent hydrogenation step. The ortho-hydroxypyridine group is known to form an ortho-oxyanion that may serve as a base to trap the proton of 1-butanol to accelerate the dehydrogenation step [47]. The Cp*Ir complex with a strong electron-donating ortho-oxyanion generated in situ may favor the hydrogenation step involved in the Guerbet reaction of 1-butanol [40].

\section{Table 1}

Guerbet reaction of 1-butanol to 2-EH by using a $\mathrm{Cp}^{*} \mathrm{Ir}$ complex as catalyst.

\begin{tabular}{|c|c|c|c|c|c|c|c|}
\hline & & & & & 2-EHE & & EH \\
\hline \multirow{2}{*}{ Entry } & \multirow{2}{*}{ Catalyst } & \multirow{2}{*}{$T\left({ }^{\circ} \mathrm{C}\right)$} & \multirow{2}{*}{ TON } & \multicolumn{4}{|c|}{ Selectivity (\%) } \\
\hline & & & & 2-EHA & 2-EEA & 2-EHE & 2-EH \\
\hline 1 & {$\left[\mathrm{Cp}^{*} \mathrm{IrCl}_{2}\right]_{2}$} & 120 & 411 & 4.1 & 2.9 & 18.7 & 74.3 \\
\hline 2 & [Cp*IrClL1]Cl & 120 & 629 & 3.8 & 7.6 & 26.6 & 62.0 \\
\hline 3 & [Cp*IrClL2]Cl & 120 & 1124 & 3.5 & 6.9 & 27.6 & 62.0 \\
\hline 4 & {$[\mathrm{Cp} * \mathrm{IrClL} 3] \mathrm{Cl}$} & 120 & 2900 & 1.1 & 6.1 & 15.0 & 77.8 \\
\hline 5 & {$[\mathrm{Cp} * \mathrm{IrClL} 4] \mathrm{Cl}$} & 120 & 2192 & 1.3 & 5.4 & 17.7 & 75.6 \\
\hline 6 & {$[\mathrm{Cp} * \mathrm{IrClL} 3] \mathrm{Cl}$} & 130 & 3492 & 0.7 & 4.5 & 8.4 & 86.4 \\
\hline
\end{tabular}

Reaction conditions: Cp*Ir complex (0.5 $\mu \mathrm{mol}), 1$-butanol $(2 \mathrm{~g})$, and $\mathrm{KOH}$ (30 mg) under $\mathrm{N}_{2}$ atmosphere (10 bar) for $6 \mathrm{~h}$.
We previously reported that the hydrogenation performance of the Cp*Ir complex was enhanced when ligand L2 was tuned to produce a more electron-rich variation [40]. Considering that the hydrogenation step is also involved in the Guerbet reaction, a $\mathrm{Cp}^{*} \mathrm{Ir}$ complex bearing a stronger electron-donating group on ligand L2 may be expected to increase the activity of the Guerbet reaction of 1-butanol by enhancing the hydrogenation activity. Therefore, we studied the catalytic performance of the [Cp*IrClL3]Cl and [Cp*IrClL4]Cl complexes bearing the electron-donating groups, para- $\mathrm{NMe}_{2}$, and $p a-$ ra-morpholine, respectively (Table 1, entries 4 and 5). Compared with the [Cp*IrClL2]Cl complex (Table 1, entry 3), both the yield and selectivity of 2-EH were significantly increased. As a result, the [Cp*IrClL3]Cl complex bearing an electron-donating para-NMe2 group exhibited higher catalytic activity (Table 1, entry 4). Upon further increasing the reaction temperature to $130{ }^{\circ} \mathrm{C}$, the TON of the [Cp*IrClL3]Cl complex reached a maximum of 3492 (Table 1, entry 6).

The Guerbet reaction of 1-butanol to 2-EH was then carried out by prolonging the reaction time to $48 \mathrm{~h}$ at $130{ }^{\circ} \mathrm{C}$, resulting in a 2 -EH yield of $23.9 \%$ and a 2 -EH selectivity of $89.5 \%$ (Supporting Information). A TOF of $564 \mathrm{~h}^{-1}$ was achieved using the [Cp*IrClL3]Cl complex as the catalyst after half an hour. Significantly, the catalytic performance of the [Cp*IrClL3]Cl complex was further tested at a catalyst charge as low as $1.6 \times 10^{-5}$ mol\%, and a record TON of 14047 was reached (Supporting Information). The results indicate that the catalyst is highly active, while maintaining a high stability under the reaction conditions to achieve a high TON.

We studied the effect of the base amount on the Guerbet reaction of 1-butanol with the [Cp*IrClL3]Cl complex as a catalyst. As shown in Fig. 1(a), upon increasing the amount of $\mathrm{KOH}$ from approximately 1.0 to $6.6 \mathrm{~mol} \%$, the TON first increased to a maximum value of 2900 and then decreased steadily. As shown in Fig. 1(b), the selectivity of the desired product 2-EH followed a similar trend to the TON curve, suggesting that approximately $1.7 \mathrm{~mol} \%$ of $\mathrm{KOH}$ is the optimum base amount for producing 2-EH from 1-butanol with the maximum TON and selectivity. The selectivity of 2-EHA and 2-EEA remained at a plateau of approximately $2 \%$ and $8 \%$, respectively. The selectivity of 2-EHE followed a trend that first decreased and then increased, probably because the hydrogenation of 2-EHE to 2-EH was suppressed with increasing amounts of $\mathrm{KOH}$.

We propose a Guerbet reaction pathway for 1-butanol to 2-EH, as shown in Scheme 3 [30-32]. 1-Butanol is dehydrogenated to butyraldehyde by [Cp*IrClL3]Cl and $\mathrm{KOH}$, followed by the $\mathrm{KOH}$-catalyzed aldol condensation of butyraldehyde to an unsaturated aldehyde, 2-EEA. 2-EEA may first undergo hydrogenation of the $\mathrm{C}=\mathrm{O}$ bond to 2-EHE (Scheme 3, path a) or hydrogenation of the $\mathrm{C}=\mathrm{C}$ bond to 2-EHA (Scheme 3, path b). Further hydrogenation of 2-EHE or 2-EHA produces the final product 2-EH. The detection of 2-EHA, 2-EEA, and 2-EHE, as shown in Table 1, demonstrates that 2-EHA, 2-EEA, and 2-EHE are intermediates.

To understand the factors that determine the pathway and product selectivity involving the observed intermediates as shown in Scheme 3, the multiple potentially competing aldol 

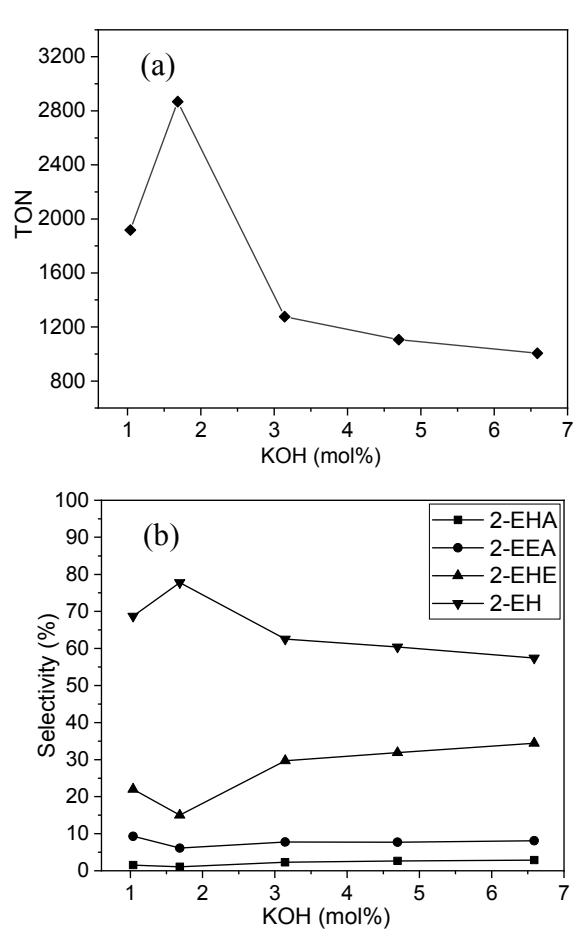

Fig. 1. (a) Effect of the amount of $\mathrm{KOH}$ on TON by using the [Cp*IrClL3]Cl complex as the catalyst (conditions: $0.5 \mu \mathrm{mol}$ of [Cp*IrClL3]Cl, and $2 \mathrm{~g}$ of 1-butanol under $10 \mathrm{bar}$ of $\mathrm{N}_{2}$ atmosphere at $120^{\circ} \mathrm{C}$ for $6 \mathrm{~h}$ ); (b) The effect of the amount of $\mathrm{KOH}$ on the selectivity by using [Cp*IrClL3]Cl as the catalyst (conditions: $0.5 \mu \mathrm{mol}$ of [Cp*IrClL3] Cl and $2 \mathrm{~g}$ of 1-butanol under 10 bar of $\mathrm{N}_{2}$ atmosphere at $120^{\circ} \mathrm{C}$ for $6 \mathrm{~h}$ ).

reactions of butyraldehyde, 2-EHA, and 2-EEA were studied (Scheme 4). The self-aldol reaction of butyraldehyde produced 2-EEA as a major product with a conversion of $73.7 \%$ and yield of $72.6 \%$. In the presence of 2-EHA, the self-aldol product, 2-EEA, from butyraldehyde was still obtained with a yield of $68.7 \%$, while the cross-aldol product, 2,4-diethyloct-2-enal, was only obtained with a yield of $3.2 \%$. The reduced cross-aldol reaction of 2-EHA with butyraldehyde was probably due to the steric effect of the ethyl group on the $\alpha$-C. In the presence of 2-EEA, the self-aldol reaction of butyraldehyde to 2-EEA was not influenced. The cross-aldol product, 2,4-diethylocta2,4-dienal, was not detected, indicating that the $\mathrm{C}=\mathrm{C}-\mathrm{C}=\mathrm{O}$ conjugation effect suppressed the cross-aldol reaction of 2-EEA with butyraldehyde. As a result, for the Guerbet catalysis of 1-butanol, the conjugation effect and steric hindrance on the $\alpha$-C of aldehyde intermediates enhanced the selectivity of the Guerbet alcohol, 2-EH, by suppressing the cross-aldol reaction of 2-EHA and 2-EEA with butyraldehyde.

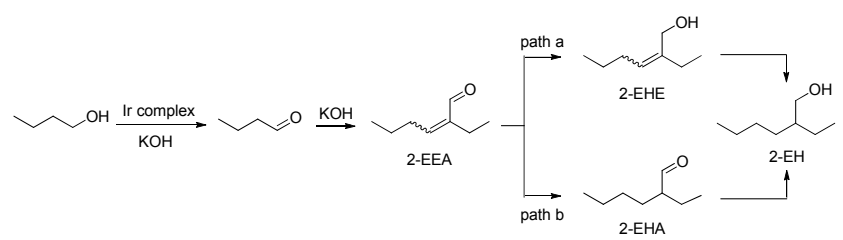

Scheme 3. Proposed pathways of the Guerbet reaction of 1-butanol to 2-EH.

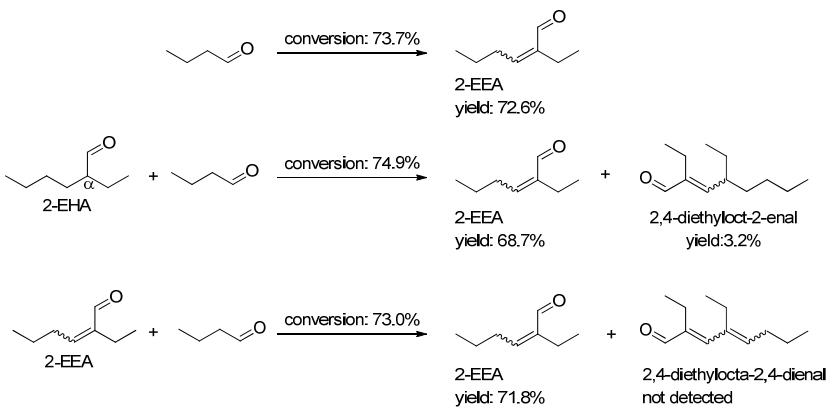

Scheme 4. Steric and conjugation effects on product selectivity in the aldol reactions of butyraldehyde, 2-EHA, and 2-EEA. Reaction conditions: butyraldehyde (1 mmol), 2-EHA (0.5 mmol), 2-EEA $(0.5 \mathrm{mmol})$, $\mathrm{KOH}$ (30 mg), 1-butanol (2 g), at $25^{\circ} \mathrm{C}$ for $5 \mathrm{~min}$.

To verify the rate-determining factor in the hydrogenation pathway of the unsaturated aldehyde, 2-EEA, the selective hydrogenation of 2-EEA catalyzed by the $\mathrm{Cp} * \mathrm{Ir}$ complex was studied as a model (Supporting Information). The hydrogenation products, 2-EHA, 2-EHE, and 2-EH were obtained with selectivities of $20.0 \%, 31.5 \%$, and $39.7 \%$, respectively. The results of hydrogenation of 2-EHA and 2-EHE to 2-EH are shown in Table 2. The blank reaction exhibited no Guerbet product generated from 1-butanol under the reaction conditions (Table 2, entry 1). The reaction rate measured by the TOF of 2-EHA hydrogenation to 2-EH (1409 $\mathrm{h}^{-1}$, entry 2, Table 2) was much higher than that of 2-EHE hydrogenation to 2-EH (56 $\mathrm{h}^{-1}$, entry 3 , Table 2). The rates of TOF on 2-EHA and 2-EHE hydrogenations, as shown in Table 2, indicate that the hydrogenation of $-\mathrm{C}=\mathrm{O}$ is kinetically favored over that of $-\mathrm{C}=\mathrm{C}-$ by the [Cp*IrClL3]Cl catalyst. The kinetics of the hydrogenation of these model compounds help to explain the intermediates observed in Fig. 1. As a result, for the Guerbet reaction of 1-butanol to 2-EH shown in Table 1, the selectivity of 2-EHE is generally higher than that of 2-EHA because the consumption rate of 2-EHE to 2-EH is much slower than that of 2-EHA to 2-EH.

The [Cp* IrClL3]Cl complex is proposed to react with $\mathrm{KOH}$, forming the [Cp*IrClL3'] complex that bears an ortho-oxyanion group driven by the neutralization of $\mathrm{HCl}$ with a strong base, $\mathrm{OH}^{-}$(Scheme 5) [36,49]. Further ligand exchange between $\mathrm{OH}^{-}$ and $\mathrm{Cl}^{-}$in the [Cp*IrClL3'] complex led to the formation of the [Cp* $\left.\operatorname{Ir}(\mathrm{OH}) \mathrm{L3}^{\prime}\right]$ complex [36]. As the [Cp* $\left.\operatorname{Ir}(\mathrm{OH}) \mathrm{L3}^{\prime}\right]$ complex

Table 2

Control experiments for the hydrogenation of 2-EHA and 2-EHE.

\begin{tabular}{lccc}
\hline Entry & Substrate & $\mathrm{TOF}\left(\mathrm{h}^{-1}\right)$ & Selectivity (\%) \\
\hline 1 & 1409 & - \\
3
\end{tabular}

Reaction conditions: [Cp*IrClL3]Cl $(0.4 \mu \mathrm{mol})$, 1-butanol (1 g), substrate $(1 \mathrm{mmol})$, and $\mathrm{KOH}(1 \mathrm{mg})$ under $\mathrm{H}_{2}$ atmosphere $(10 \mathrm{bar})$ at 120 ${ }^{\circ} \mathrm{C}$ for $20 \mathrm{~min}$. 


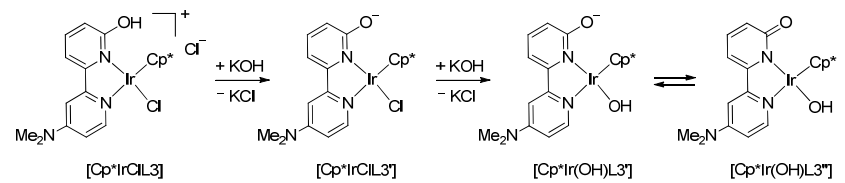
Scheme 5. The proposed reaction of [Cp*IrClL3]Cl complex with $\mathrm{KOH}$.

could be rearranged to form a [Cp* $\left.\operatorname{Ir}(\mathrm{OH}) \mathrm{L}^{\prime}\right]$ complex that bears an ortho-carbonyl group, we studied the reaction of the [Cp*IrClL3]Cl complex with $\mathrm{KOH}$ by ${ }^{1} \mathrm{H}$ NMR and ${ }^{13} \mathrm{C}$ NMR (Supporting Information). In Fig. 2(a), the peaks $(6.3<\delta<8.5)$ are assigned to the bipyridine ring of the [Cp*IrClL3]Cl complex. In the presence of $\mathrm{KOH}$, a significant change in the ${ }^{1} \mathrm{H}$ NMR spectrum from that of the [ $\left.\mathrm{Cp}^{*} \mathrm{IrClL} 3\right] \mathrm{Cl}$ complex was observed, indicating that a [Cp* $\operatorname{Ir}(\mathrm{OH}) \mathrm{L} 3 "]$ complex with a carbonyl group on the bipyridine ring (Fig. 2(b)) is generated from the reaction of the [Cp*IrClL3]Cl complex with $\mathrm{KOH}$. For the corresponding ${ }^{13} \mathrm{C}$ NMR spectrum, as shown in Fig. 2(c), the peaks $(100<\delta<175)$ are assigned to the bipyridine ring of the [Cp*IrClL3]Cl complex, and the peak ( $\delta=164.0$, Fig. 2(c)) is assigned to $\mathrm{C} 2$ of the bipyridine ring [34,47]. In the presence of $\mathrm{KOH}$, a significant change in the position of $\mathrm{C} 2$ in the ${ }^{13} \mathrm{C}$ NMR spectrum ( $\delta=171.6$, Fig. 2(d)) supported the formation of a carbonyl group in the [Cp*Ir(OH)L3"] complex $[36,49]$.
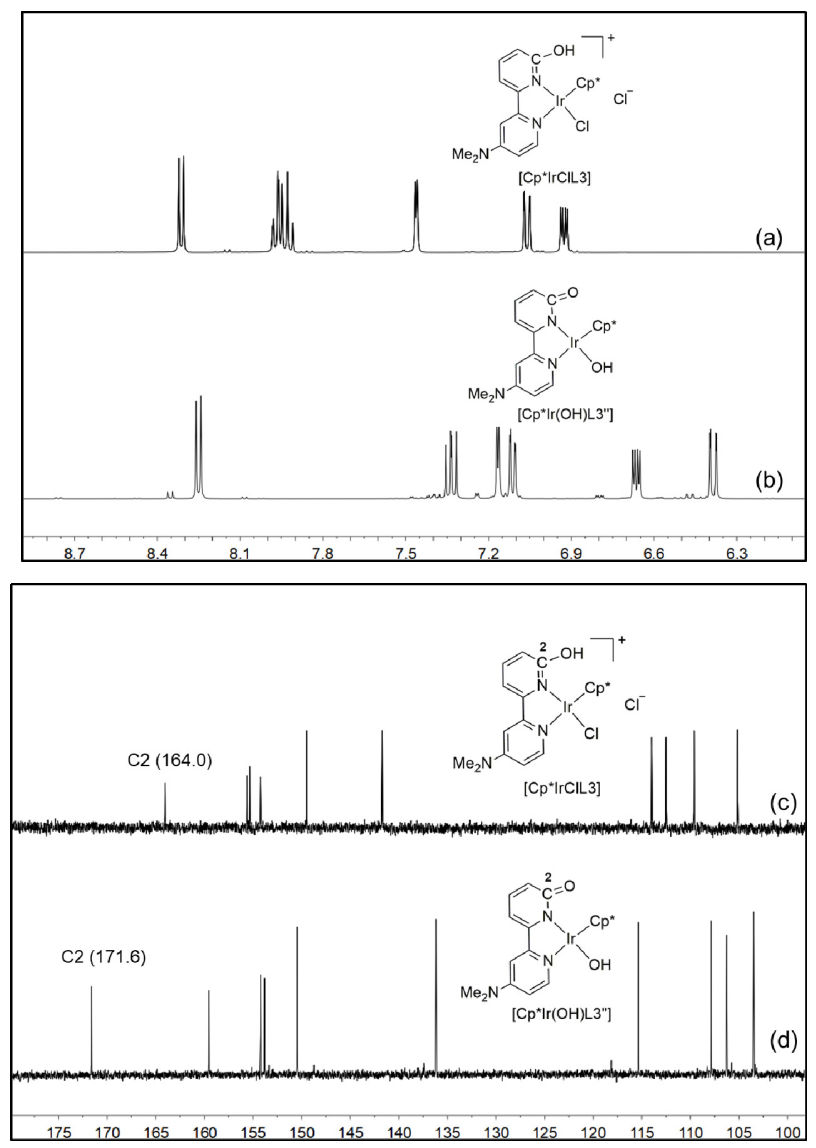

Fig. 2. The ${ }^{1} \mathrm{H}$ NMR and ${ }^{13} \mathrm{C}$ NMR spectra of the [Cp*IrClL3]Cl complex with/without KOH. (a) The ${ }^{1} \mathrm{H}$ NMR spectrum of [Cp*IrClL3]Cl without $\mathrm{KOH}$; (b) The ${ }^{1} \mathrm{H}$ NMR spectrum of [Cp*IrClL3]Cl with $\mathrm{KOH}$; (c) The ${ }^{13} \mathrm{C}$ NMR spectrum of [Cp*IrClL3]Cl without $\mathrm{KOH}$; (d) The ${ }^{13} \mathrm{C}$ NMR spectrum of [Cp*IrClL3]Cl with $\mathrm{KOH}$.

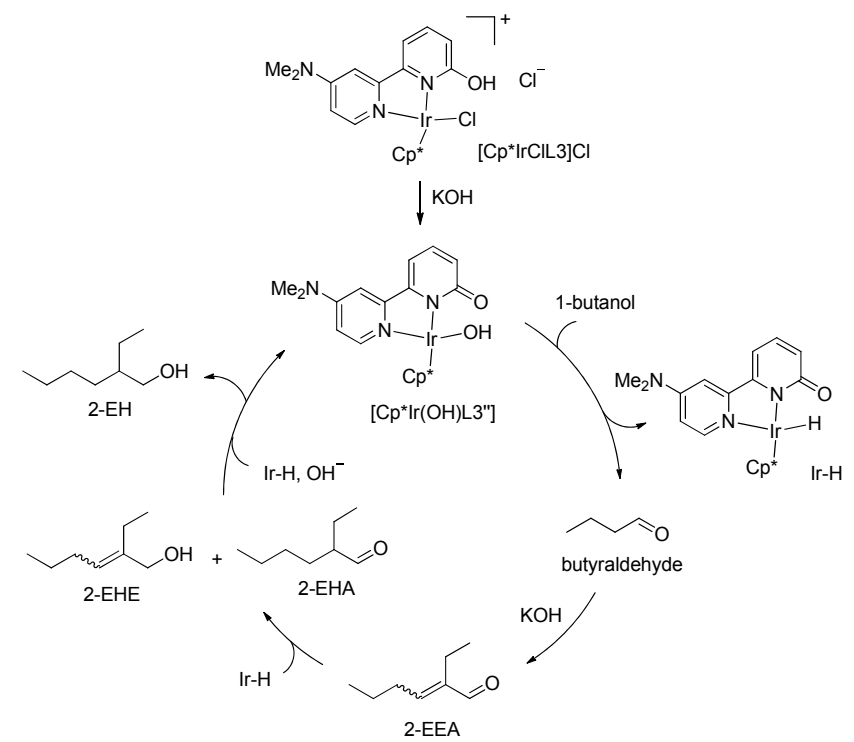

Scheme 6. The proposed mechanism of the Guerbet reaction of 1-butanol to 2-EH.

Based on the above experimental results, we further propose a mechanism for the $\mathrm{Cp}$ *Ir complex-catalyzed Guerbet reaction of 1-butanol to 2-EH (Scheme 6). The [Cp*IrClL3]Cl complex may first react with $\mathrm{KOH}$ to form the active catalyst, [Cp*Ir(OH)L3"] (Scheme 5) [36,49], followed by the dehydrogenation of 1-butanol to form the catalyst, Ir-H, and butyraldehyde [35]. The $\mathrm{KOH}$-catalyzed aldol reaction of butyraldehyde produces an unsaturated aldehyde, 2-EEA. The aldehyde (2-EEA) is hydrogenated with the catalyst, Ir-H, to intermediate products, 2-EHA and 2-EHE, and further to 2-EH with the regenerated [Cp* $\mathrm{Ir}(\mathrm{OH}) \mathrm{L} 3 "]$-catalyst. The hydrogenation activity of the catalyst (Ir-H) was significantly enhanced with ligand L3, bearing a strong electron-rich para- $\mathrm{NMe}_{2}$ group and an ortho-hydroxypyridine group. The ethyl group on the $\alpha$-C and the conjugation effect of the $\mathrm{C}=\mathrm{C}$ double bond inhibits the further cross-aldol reaction of 2-EHA and 2-EEA with butyraldehyde, resulting in an increase in selectivity in the Guerbet reaction of 1-butanol to produce 2-EH.

\section{Conclusions}

We have demonstrated an efficient homogeneous system for the catalytic Guerbet reaction of 1-butanol to produce 2-ethyl-1-hexanol. The catalytic activity of the $\mathrm{Cp}$ *Ir complex increased when the electron density of the ligand was increased by introducing a para- $\mathrm{NMe}_{2}$ group, an ortho-hydroxypyridine group, and a $\mathrm{Cl}^{-}$anion. A record TON of 14047 was attained. The ethyl group on the $\alpha$-C of 2-EHA and the conjugation effect of the $\mathrm{C}=\mathrm{C}$ double bond of 2-EEA are found to benefit the high selectivity of 2-EH from 1-butanol by inhibiting the cross-aldol reaction of 2-EHA and 2-EEA with butyraldehyde. The NMR study revealed the formation of a carbonyl group in the bipyridine-type ligand via the reaction of the $\mathrm{Cp}^{*} \mathrm{Ir}$ complex with $\mathrm{KOH}$. The new mechanistic understanding represents an important addition to the suite of Guerbet catalysis and hydrogen-borrowing chemistry. Further 
improvement of the catalyst efficiency based on the mechanistic understanding and development of a homogeneous catalytic process for the economic production of higher alcohols from 1-butanol or ethanol is underway.

\section{Electronic supporting information.}

Supporting information is available in the online version of this article

\section{Notes}

The authors declare no competing financial interest.

\section{References}

[1] J. Ma, L. Xu, L. Xu, H. Wang, S. Xu, H. Li, S. Xie, H. Li, ACS Catal,, 2013, 3, 985-992.

[2] S. K. Sharma, R. V. Jasra, Ind. Eng. Chem. Res., 2011, 50, 2815-2821.

[3] L. Zhao, Y. Wang, H. An, X. Zhao, Y. Wang, Catal. Commun., 2018, 103, 74-77.

[4] G. M. Torres, R. Frauenlob, R. Franke, A. Börner, Catal. Sci. Technol., 2015, 5, 34-54.

[5] Y. Li, X. Liu, H. An, X. Zhao, Y. Wang, Ind. Eng. Chem. Res., 2016, 55, 6293-6299.

[6] N. Liang, X. Zhang, H. An, X. Zhao, Y. Wang, Green Chem., 2015, 17, 2959-2972.

[7] R. L. Wingad, P. J. Gates, S. T. G. Street, D. F. Wass, ACS Catal., 2015, 5, 5822-5826.

[8] R. Mazzoni, C. Cesari, V. Zanotti, C. Lucarelli, T. Tabanelli, F. Puzzo, F. Passarini, E. Neri, G. Marani, R. Prati, F. Viganò, A. Conversano, F. Cavani, ACS Sustainable Chem. Eng., 2019, 7, 224-237.

[9] V. N. Panchenko, E. A. Paukshtis, D. Y. Murzin, I. L. Simakova, Ind.
Eng. Chem. Res., 2017, 56, 13310-13321.

[10] G. R. M. Dowson, M. F. Haddow, J. Lee, R. L. Wingad, D. F. Wass, Angew. Chem. Int. Ed., 2013, 52, 9005-9008.

[11] R. L. Wingad, E. J. E. Bergström, M. Everett, K. J. Pellow, D. F. Wass, Chem. Commun., 2016, 52, 5202-5204.

[12] T. Moteki, D. W. Flaherty, ACS Catal., 2016, 6, 4170-4183.

[13] C. N. Neumann, S. J. Rozeveld, M. Yu, A. J. Rieth, M. Dincă, J. Am. Chem. Soc., 2019, 141, 17477-17481.

[14] K.-N. T. Tseng, S. Lin, J. W. Kampf, N. K. Szymczak, Chem. Commun., 2016, 52, 2901-2904.

[15] H. Aitchison, R. L. Wingad, D. F. Wass, ACS Catal., 2016, 6, 7125-7132.

[16] Y. Xie, Y. Ben-David, L. J. W. Shimon, D. Milstein, J. Am. Chem. Soc., 2016, 138, 9077-9080.

[17] H. Li, A. Riisager, S. Saravanamurugan, A. Pandey, R. S. Sangwan, S. Yang, R. Luque, ACS Catal., 2018, 8, 148-187.

[18] Q. Liu, G. Xu, X. Wang, X. Liu, X. Mu, ChemSusChem, 2016, 9, 3465-3472.

[19] G. Xu, T. Lammens, Q. Liu, X. Wang, L. Dong, A. Caiazzo, N. Ashraf, J. Guana, X. Mu, Green Chem., 2014, 16, 3971-3977.

[20] S. Chakraborty, P. E. Piszel, C. E. Hayes, R. T. Baker, W. D. Jones, J. Am. Chem. Soc., 2015, 137, 14264-14267.

[21] E. M. Green, Curr. Opin. Biotechnol., 2011, 22, 337-343.

[22] C. Jin, M. Yao, H. Liu, C.-F. Lee, J. Ji, Renew. Sust. Energy Rev., 2011, $15,4080-4106$.

[23] A. Prakash, R. Dhabhai, V. Sharma, Curr. Biochem. Eng., 2015, 3, 37-46.

[24] J. C. Liao, L. Mi, S. Pontrelli, S. Luo, Nat. Rev. Microbiol., 2016, 14, 288-304.

[25] M. H. S. A. Hamid, P. A. Slatford, J. M. J. Williams, Adv. Synth. Catal., 2007, 349, 1555-1575.

[26] G. E. Dobereiner, R. H. Crabtree, Chem. Rev., 2010, 110, 681-703.

[27] D. Liu, X. Chen, G. Xu, J. Guan, Q. Cao, B. Dong, Y. Qi, C. Li, X. Mu, Sci. Rep., 2016, 6, 21365.

[28] C. Carlini, A. Macinai, A. M. R. Galletti, G. Sbrana, J. Mol. Catal. A,

\section{Graphical Abstract}

Chin. J. Catal., 2021, 42: 1586-1592 doi: 10.1016/S1872-2067(20)63772-X

Electronic and steric factors for enhanced selective synthesis of 2-ethyl-1-hexanol in the Ir-complex-catalyzed Guerbet reaction of 1-butanol

Zhanwei Xu, Peifang Yan, Changhui Liang, Songyan Jia, Xiumei Liu, Z. Conrad Zhang *

Dalian Institute of Chemical Physics, Chinese Academy of Sciences; University of Chinese Academy of Sciences;

Shenyang University of Chemical Technology

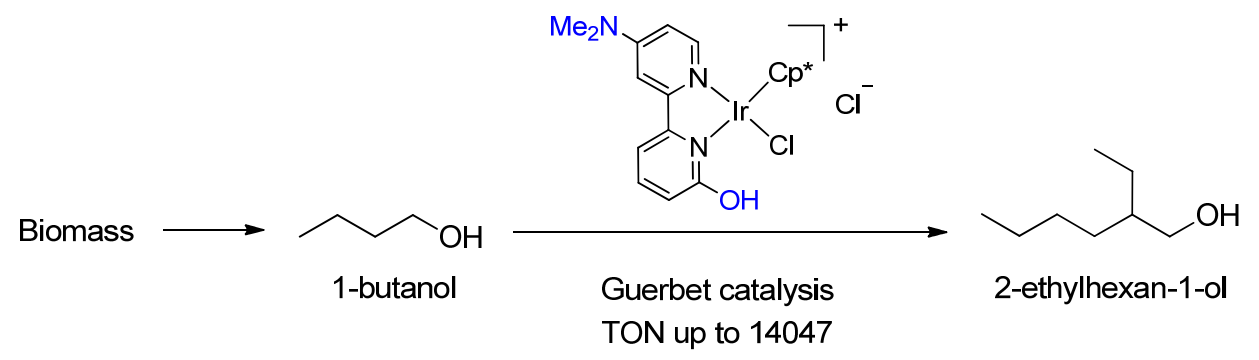

An enhanced catalytic Guerbet reaction of 1-butanol to 2-ethyl-1-hexanol by a Cp* Ir complex was reported. 
2004, 212, 65-70.

[29] V. N. Panchenko, E. A. Paukshtis, D. Yu. Murzin, I. L. Simakova, Ind. Eng. Chem. Res., 2017, 56, 13310-13321.

[30] T. Matsu-ura, S. Sakaguchi, Y. Obora, Y. Ishii, J. Org. Chem., 2006, 71, 8306-8308.

[31] G. Xu, T. Lammens, Q. Liu, X. Wang, L. Dong, A. Caiazzo, N. Ashraf, J. Guana, X. Mu, Green Chem., 2014, 16, 3971-3977.

[32] S. Hanspal, Z. D. Young, J. T. Prillaman, R. J. Davis, J. Catal., 2017, 352, 182-190.

[33] A. V. Chistyakov, P. A. Zharova, S. A. Nikolaev, M. V. Tsodikov, Catal. Today, 2017, 279, 124-132;

[34] W. Y. Hernández, K. De Vlieger, S. Clerick, P. Van Der Voort, A. Verberckmoes, Catal. Commun., 2017, 98, 94-97.

[35] K. Sordakis, C. Tang, L. K. Vogt, H. Junge, P. J. Dyson, M. Beller, G. Laurenczy, Chem. Rev., 2018, 118, 372-433.

[36] K. Fujita, R. Kawahara, T. Aikawa, R. Yamaguchi, Angew. Chem. Int. Ed., 2015, 54, 9057-9060.

[37] K. Fujita, Y. Tanaka, M. Kobayashi, R. Yamaguchi, J. Am. Chem. Soc., 2014, 136, 4829-4832.

[38] W. P. Wu, Y. J. Xu, R. Zhu, M. S. Cui, X. L. Li, J. Deng, Y. Fu, ChemSusChem, 2016, 9, 1209-1215.

[39] Z. Xu, P. Yan, W. Xu, X. Liu, Z. Xia, B. Chung, S. Jia, Z. C. Zhang, ACS
Catal., 2015, 5, 788-792.

[40] Z. Xu, P. Yan, H. Li, K. Liu, X. Liu, S. Jia, Z. C. Zhang, ACS Catal., 2016, 6, 3784-3788.

[41] N. Onishi, S. Xu, Y. Manaka, Y. Suna, W.-H. Wang, J. T. Muckerman, E. Fujita, Y. Himeda, Inorg. Chem., 2015, 54, 5114-5123.

[42] J. F. Hull, Y. Himeda, W.-H. Wang, B. Hashiguchi, R. Periana, D. J. Szalda, J. T. Muckerman, E. Fujita, Nat. Chem., 2012, 4, 383-388.

[43] W.-H. Wang, S. Xu, Y. Manaka, Y. Suna, H. Kambayashi, J. T. Muckerman, E. Fujita, Y. Himeda, ChemSusChem, 2014, 7, 1976-1983.

[44] W.-H. Wang, J. F. Hull, J. T. Muckerman, E. Fujita, Y. Himeda, Energy Environ. Sci., 2012, 5, 7923-7926.

[45] Y. Suna, M. Z. Ertem, W.-H. Wang, H. Kambayashi, Y. Manaka, J. T. Muckerman, E. Fujita, Y. Himeda, Organometallics, 2014, 33, 6519-6530.

[46] W.-H. Wang, M. Z. Ertem, S. Xu, N. Onishi, Y. Manaka, Y. Suna, H. Kambayashi, J. T. Muckerman, E. Fujita, Y. Himeda, ACS Catal, 2015, 5, 5496-5504.

[47] W.-H. Wang, J. T. Muckerman, E. Fujita, Y. Himeda, ACS Catal., 2013, 3, 856-860.

[48] W.-H. Wang, Y. Himeda, J. T. Muckerman, G. F. Manbeck, E. Fujita, Chem. Rev., 2015, 115, 12936-12973.

[49] K.-I. Fujita, N. Tanino, R. Yamaguchi, Org. Lett., 2007, 9, 109-111.

\title{
电子和空间位阻效应促进铱配合物催化1-丁醇经Guerbet反应选择制备2-乙基己醇
}

\author{
许占威 ${ }^{\mathrm{a}}$, 颜佩芳 ${ }^{\mathrm{a}}$, 梁长慧 ${ }^{\mathrm{a}, \mathrm{b}}$, 贾松岩 ${ }^{\mathrm{c}}$, 刘秀梅 ${ }^{\mathrm{a}}$, 张宗超 ${ }^{\mathrm{a}, *}$ \\ ${ }^{a}$ 中国科学院大连化学物理研究所, 洁净能源国家实验室(筹), 催化国家重点实验室, 辽宁大连 110623 \\ ${ }^{b}$ 中国科学院大学, 北京 100049 \\ c沈阳化工大学化工学院, 辽宁沈阳 110142
}

摘要: 2-乙基己醇是一种增塑剂醇, 可用于合成增塑剂、表面活性剂和溶剂等诸多化工领域. 目前工业上2-乙基己醇的合成 是以化石资源丙烯为原料,与氢气和一氧化碳通过氢甲酰化反应制备1-丁醛, 后者经羟醛缩合和催化加氢反应生成2-乙基 己醇. 由生物质发酵产生的1-丁醇为原料, 只需要经Guerbet反应可一步直接生成2-乙基已醇. 比较而言, Guerbet反应路线 步骤更少, 且1-丁醇原位脱氢产生的氢为氢源, 无需额外氢, 因此比化石资源丙烯路线对环境友好. 目前, 文献报道的非均 相催化1-丁醇Guerbet反应条件苛刻(如温度 $>170^{\circ} \mathrm{C}$ ), 副产物多(如烯烃、醚和高碳醇等), 且均相催化剂的活性低.

本文报道了一类 $\mathrm{Cp} * \operatorname{Ir}(\mathrm{Cp} *$ 为 $1,2,3,4,5$-五甲基环戊二烯基)配合物用于该Guerbet反应. 当 $\mathrm{Cp}$ * $\operatorname{Ir}$ 配合物的配体上修饰给 电子基 $N, N$-二甲基氨基和邻羟基时, $\mathrm{Cp} *$ Ir 配合物的催化活性增强, 催化剂的转化数最高达到了 14047. 当氢氧化钾和 $\mathrm{Cp} * \mathrm{Ir}$ 配合物(配体上修饰了 $\mathrm{N}, \mathrm{N}$-二甲基氨基和邻羟基官能团)在 1 -丁醇中的浓度分别为 $1.7 \mathrm{~mol} \%$ 和 $0.04 \mathrm{wt} \%$ 时, 在 $130{ }^{\circ} \mathrm{C}$ 反 应 $48 \mathrm{~h}$, 产物2-乙基已醇收率为 $23.9 \%$, 选择性为 $89.5 \%$. 核磁(NMR)研究结果表明, $\mathrm{Cp}$ *Ir配合物配体上的邻羟基与氢氧化 钾反应脱除质子, 生成了羰基结构配体配位的 $\mathrm{Cp}$ *Ir配合物, 继续催化1-丁醇脱氢反应. 机理研究表明, 中间产物2-乙基己 醛 $\alpha$-碳上乙基的位阻效应和 2 -乙基已烯醛本身的共轭效应抑制了其继续发生羟醛反应, 从而提高了目标产物的选择性.

关键词: 2-乙基己醇; Guerbet反应; 1-丁醇; 铱; 加氢

收稿日期: 2020-12-25. 接受日期: 2021-01-22. 上网时间: 2021-05-05.

*通讯联系人. 电话/传真: (0411)84379462; 电子信箱: zczhang@yahoo.com

基金来源: 国家自然科学基金(21706255, 21932005, 21690084).

本文的电子版全文由Elsevier出版社在ScienceDirect上出版(http://www.sciencedirect.com/journal/chinese-journal-of-catalysis). 